
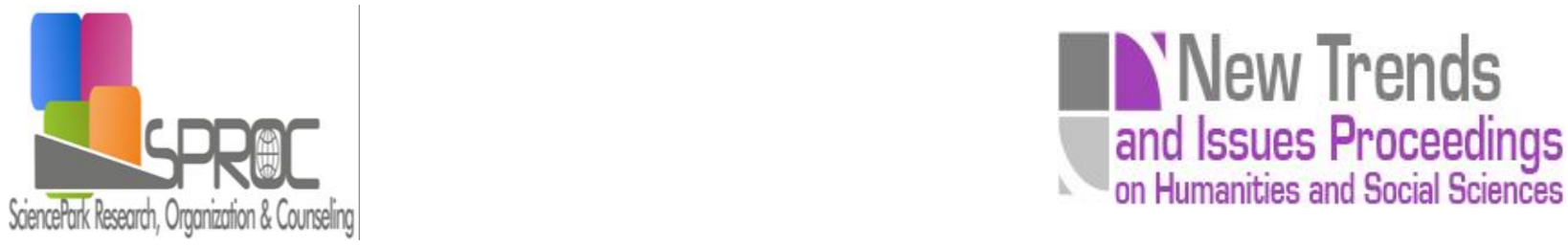

\title{
Bilingualism and bilingual educational model suggestion for Turkey
}

Kasim Karatas ${ }^{a *}$

Mehmet Fatih Ayaz ${ }^{\text {b }}$

Suggested Citation:

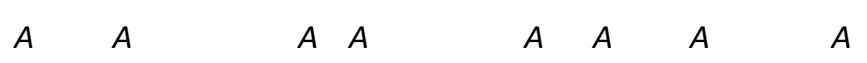

A $A$

Abstract 
1. Introduction 
A $A \quad A$

A

A

A $A$

A

A $A$

1.1. Bilingualism and bilingual education 
1.2. Bilingual educational models 
$A A A$

A

A $A$

A

A $A$ 


\section{Results and suggestions}

\section{References}

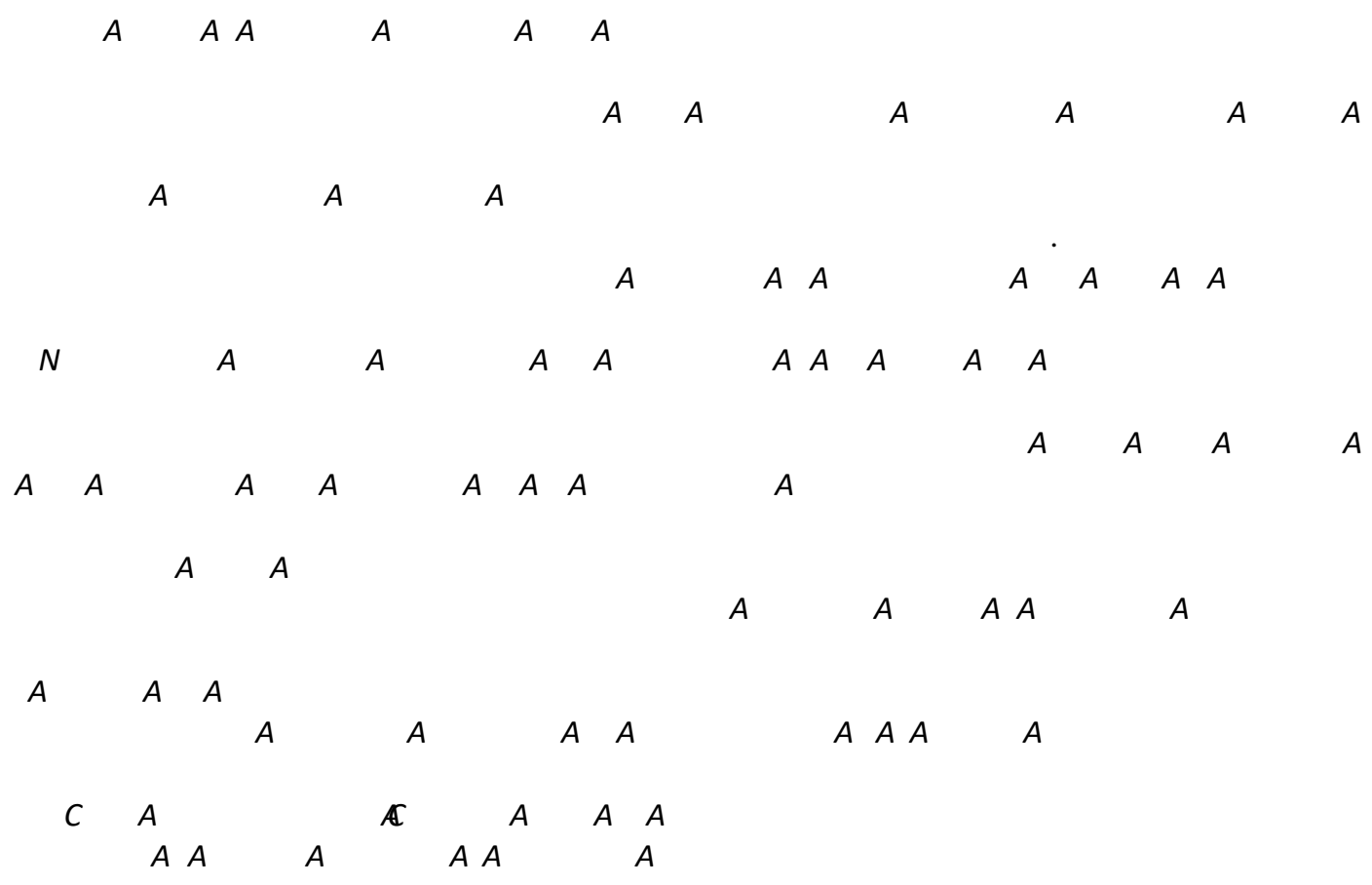




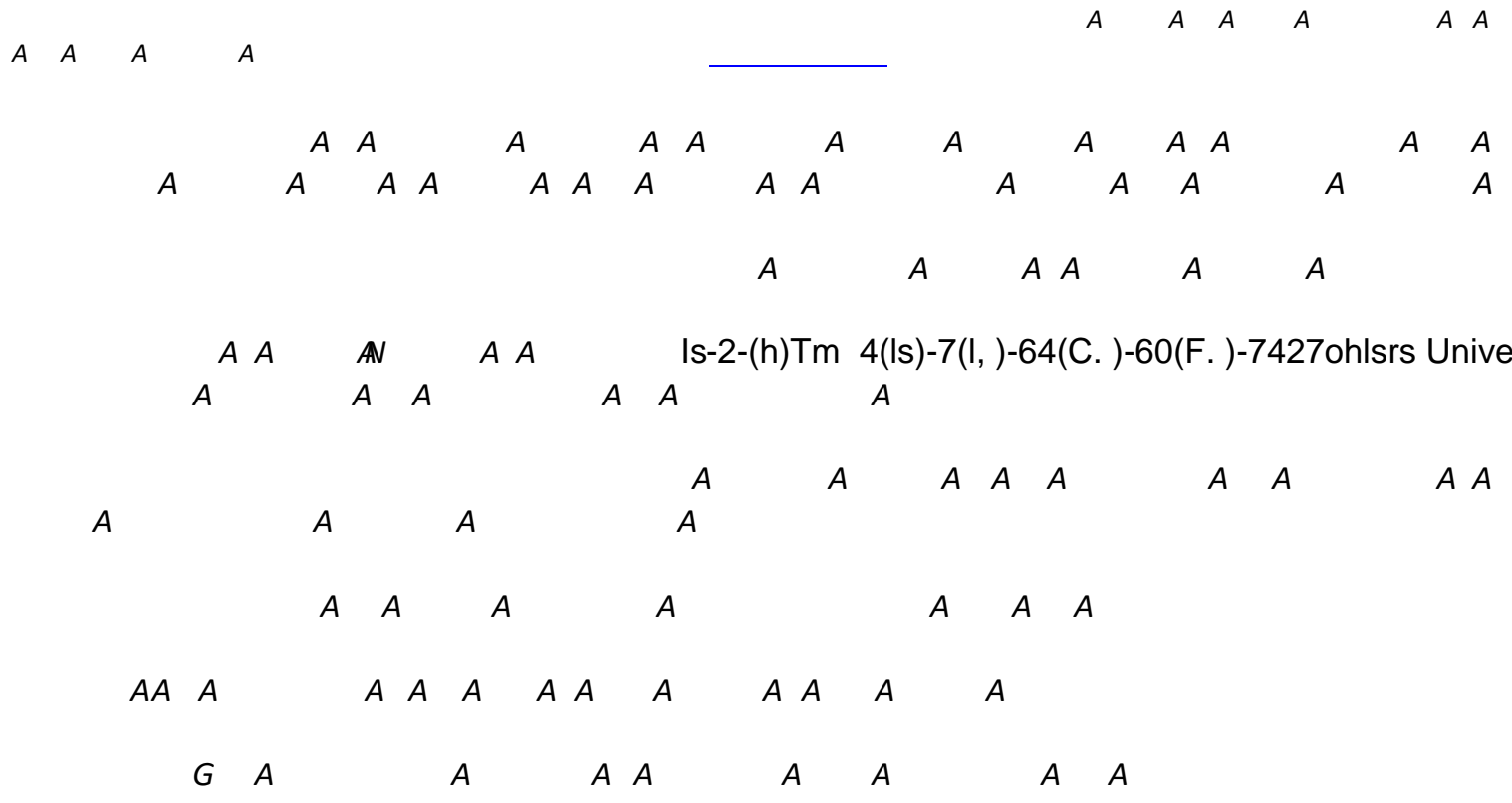

